\title{
Generation mean analysis and heritability of drought resistance in common bean (Phaseolus vulgaris L.)
}

\author{
Abebe Hinkossa ${ }^{1}$, Setegn Gebeyehu ${ }^{2 *}$ and Habtamu Zeleke ${ }^{3}$ \\ ${ }^{1}$ Bule Hora University, P. O. Box 144 Bule Hora, Ethiopia. \\ ${ }^{2}$ National Bean Research Program, Melkassa Agricultural Research Center, P. O. Box, 436, Adama, Ethiopia. \\ ${ }^{3}$ Haramaya University, P. O. Box 76, Haramaya, Ethiopia.
}

Accepted 16 April, 2013

\begin{abstract}
Information on the availability of genetic variability and mode of gene action are critically important for choosing effective breeding methods that result in appreciable improvement in performance under drought stress. The objectives of this study were to estimate the gene action for drought resistance of quantitative traits and also to estimate the components of variance and heritability of drought resistance in common bean. Field experiment was carried out using six generations of two populations made of crosses between pairs of drought resistant and susceptible genotypes (Roba-1 1 SER-16; Melka-Dima $\times$ SAB623). The treatments were laid in a split plot design with three replications, where watering regime was assigned to the main plot and generations to the sub-plot. Drought stress was initiated at flowering stage by withholding application of irrigation water. Scaling test and generation mean analysis brought out that individual crosses greatly differed for the gene action and on an overall basis all the types of gene action, additive, dominance and epistasis were important for drought resistance in common bean. Both additive and non-additive types of gene action were important in governing the inheritance of the traits considered. However, additive types of gene actions were important in the inheritance of number of pod per plant in Roba-1 $\times$ SER-16 and above ground biomass in Melka-Dima $\times$ SAB-623 under drought stress. Medium to high broad and narrow sense heritability were found for most of the traits under both watering regimes. Evidences have unfolded that chances to find stress tolerant breeding material in segregating populations of the two crosses were promising. The presence of significant amount of all types of gene action for the important traits imply that methods which can utilize all of them such as recurrent selection and multiple cross could be employed in breeding beans for drought environments.
\end{abstract}

Key words: Common bean, drought resistance, gene action, generation mean analysis, heritability, scale test.

\section{INTRODUCTION}

It is estimated that $60 \%$ of the bean crop is cultivated under the risk of either intermittent or terminal drought (Thung and Rao, 1999). Genotypic differences for drought resistance have been reported for common bean (Abebe et al., 1998). The choice of an efficient breeding program depends to a large extent on knowledge of the type of gene action involved in the expression of the character (Dabholkar, 1999). The efficiency of breeding program increases by careful choice of parents and populations capable of producing progeny with desirable trait combinations (Abreu et al., 2002; Cristina et al., 2002). Before embarking on any improvement program, genetic information regarding the inheritance of quantitative characters, particularly the nature and 
magnitude of gene action governing the inheritance of the character should be determined. The type of gene action controlling a trait is very important in decisions regarding breeding method, cultivar type (inbred, hybrid, population, etc.), and interpretation of data from quantitative genetic experiments (Lamkey and Lee, 1993).

To formulate an efficient breeding program for developing drought tolerant varieties, it is essential to understand the mode of inheritance, the magnitude of gene effects and their mode of action (Farshadfar et al., 2008). Due to their quantitative nature, drought related traits cannot be studied in simpler way. Specialized biometrical techniques are required to work out the type of genetic variability associated with the traits. These biometrical techniques are dependent on different mating designs such as diallel, line $x$ tester; North Carolina design and generation mean analysis for the estimation of type of genetic variability. Among these mating designs, generation mean analysis has been the most powerful biometrical analysis since it gives additional information about the epistatic interactions. Generation mean analysis is an approach which provides information about nature and magnitude of gene actions involved and used to estimate the component variance which provides information about the predominant type of gene action for the important characters of crop species (Ganesh and Sakila, 1999). It is based on the mean of six generations that is, $\mathrm{P}_{1}, \mathrm{P}_{2}, \mathrm{~F} 1, \mathrm{~F} 2, \mathrm{BC}_{1}$ and $\mathrm{BC}_{2}$. Information derived from these analyses can be further utilized for the formulation of an effective breeding strategy. The presence or absence of epistasis can be detected by generation means analysis using the scaling test, which measures epistasis accurately whether it is complimentary or duplicate at the digenic level (Sharmila et al., 2007). Besides gene effects, breeders would also like to know how much of the variation in a crop is genetic and to what extent this variation is heritable, because efficiency of selection mainly depends on additive genetic variance, influence of the environment and interaction between genotype and environment.

Information about the genetic components of variation helps the breeder in the selection of desirable parents for crossing programs and also in deciding a suitable breeding procedure for the genetic improvement of various quantitative traits (Singh and Narayanan, 1993). Generation means analysis has been used in common bean to study the inheritance of other complex traits such as leafhopper insect resistance (Kornegay and Temple, 1986), rate of ethylene production (Sauter et al., 1990), bean pod morphology (Chung et al., 1991), aschochyta leaf blight tolerance (Hanson et al., 1993), leaf trichome density (Park et al., 1994), and most recently heat tolerance (Rainey and Griffiths, 2005) and climbing ability (Checa et al., 2006). This study was initiated to estimate the gene action for drought resistance of quantitative traits and to estimate the component of variance and heritability of post flowering drought resistance in common bean.

\section{MATERIALS AND METHODS}

\section{Site description}

The field experiment was carried out at Melkassa Agricultural Research Center (MARC) which is found in the Central Rift Valley of Ethiopia (Figure 1). The center is located at $8^{\circ} 24^{\prime} \mathrm{N}$ latitude and $39^{\circ} 21^{\prime} \mathrm{E}$ longitudes at an altitude of 1550 masl. The climate of the area is characterized as semi-arid with mean monthly maximum and minimum temperature of 33 and $10.8^{\circ} \mathrm{C}$, respectively. The area is characterized by low and erratic rainfall with unimodal pattern of distribution. The soil is sandy clay loam (Cambisol). According to Laike et al. (2006), common bean crop coefficient during the midseason (matches with the duration of stress imposed in the present study) was 1.01 with $\mathrm{ET}_{\mathrm{c}}$ and $\mathrm{ET}_{\mathrm{o}}$ values of 234.74 and $231.75 \mathrm{~mm}$.

\section{Experimental materials}

The parents include two drought resistant (SER- 16 and SAB-623) and two susceptible (Roba-1 and Melka-Dima) common bean genotypes. Roba- 1 is a small seeded commercial cultivar sensitive to drought stress. SER-16 is small red seeded advanced breeding line from CIAT with good degree of resistance to drought. MelkaDima is another drought susceptible commercial cultivar with medium size seed. SAB6-23 is an advanced breeding line from CIAT with medium seed size and good level of tolerance to drought. Initially, two single crosses were made using the four parents: Roba-1 $\times$ SER-16 and Melka-Dima $\times$ SAB-623. The experimental material consisted of six generations for each cross. These were parents $\left(P_{1}\right.$ and $\left.P_{2}\right)$, the first and second filial generation $\left(F_{1}\right.$ and $\left.F_{2}\right)$ and back crosses $\left(\mathrm{BC}_{1}=\mathrm{P}_{1} \times \mathrm{F}_{1}\right.$ and $\left.\mathrm{BC}_{2}=\mathrm{P}_{2} \times \mathrm{F}_{1}\right)$.

\section{Development of plant material}

The four parents were planted in the field under optimal growth conditions. Normal production package and crop husbandry techniques were followed to raise the crop. The different generations that were used in this study $\left(F_{1}, F_{2}, B C_{1}\right.$, and $\left.B C_{2}\right)$ were developed through a stepwise crossing from February to September, 2010. Using the four parents, two $F_{1}$ cross combinations between tolerant and susceptible parents were made from February to June, 2010. The $F_{1}$ seeds were planted to generate $F_{2}$ population through selfing and the backcross populations $\left(\mathrm{BC}_{1}\right.$ and $\mathrm{BC}_{2}$ ) were simultaneously generated through crossing $F_{1}$ of the crosses back to parent $1\left(\mathrm{P}_{1}\right)$ and parent $2\left(\mathrm{P}_{2}\right)$ from June, 2010 to September, 2010. List of parents and crosses produced are given in Table 1.

\section{Experimental design and treatments}

The six treatments $\left(P_{1}, P_{2}, F_{1}, F_{2}, B C_{1}\right.$, and $\left.B C_{1}\right)$ for each population were planted in split plot design with watering regime as a main plot and generations were assigned to sub-plots. Overall, twelve generations $\left(2 \mathrm{P}_{1}, 2 \mathrm{P}_{2}, 2 \mathrm{~F}_{1}, 2 \mathrm{~F}_{2}, 2 \mathrm{BC}_{1}\right.$ and $\left.2 \mathrm{BC}_{2}\right)$ were grown under two contrasting watering regimes, non-stress (NS) and drought-stress (DS) and the treatments were replicated three times. Planting was done late in season $\left(4^{\text {th }}\right.$ week of September, 2010$)$ to expose the drought stressed treatments to terminal stress when the main season rain ceases. For the stress treatments, terminal drought was induced stressed by withholding application of irrigation at flowering stage.

Soil moisture measurement (centibars) was taken using water 


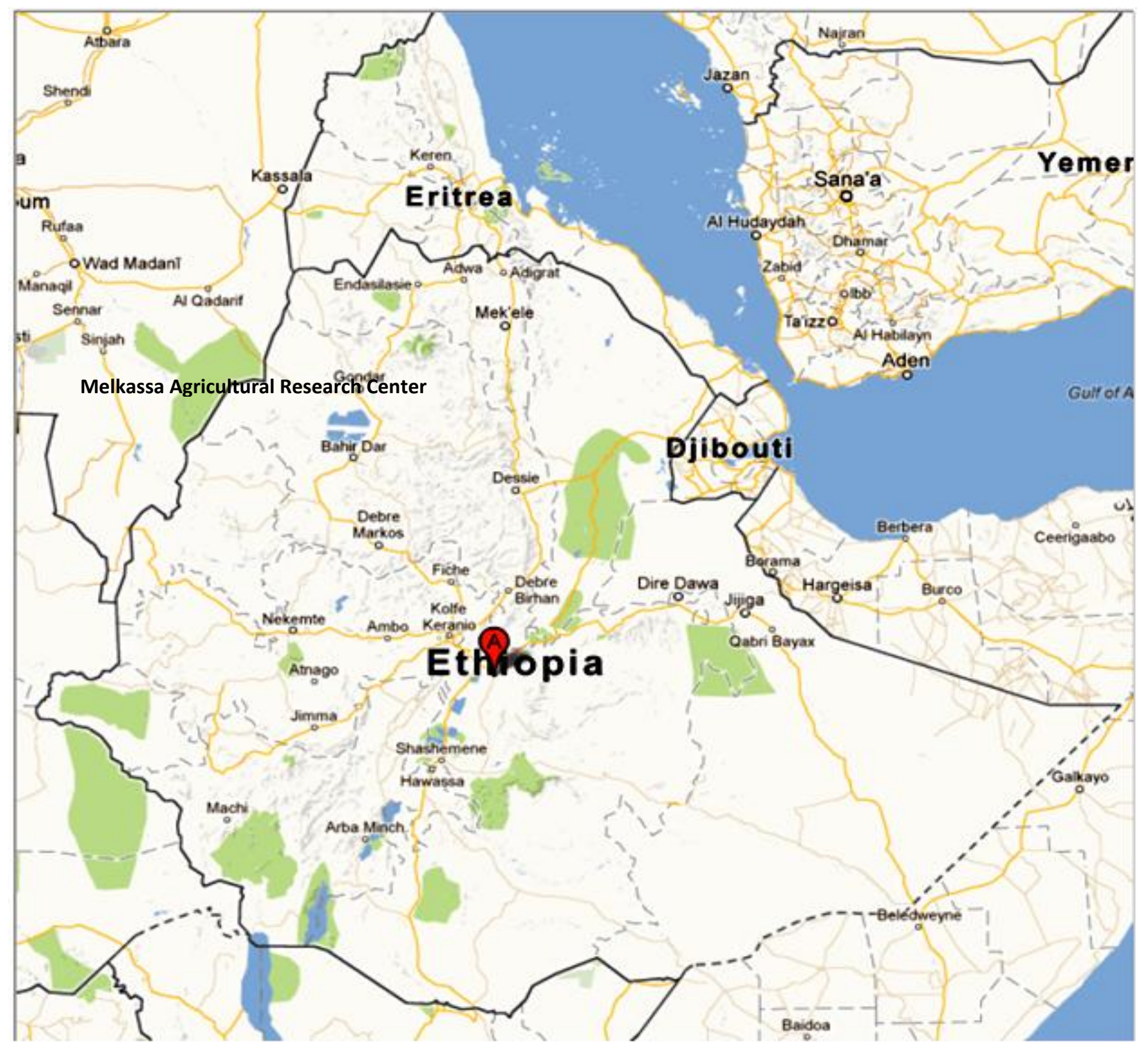

Figure 1. Location of Melkassa Agricultural Research Center.

Table 1. List of parents and crosses produced.

\begin{tabular}{cll}
\hline Generation & Parents and crosses (Population 1) & Parents and crosses (Population 2) \\
\hline$P_{1}$ & SER-16 & SAB-623 \\
$\mathrm{P}_{2}$ & Roba-1 & Melka-Dima \\
$\mathrm{F}_{1}$ & Roba-1 $\times$ SER-16 & Melka-Dima $\times$ SAB-623 \\
$\mathrm{F}_{2}$ & Roba-1 $\times$ SER-16 & Melka-Dima $\times$ SAB-623 \\
$\mathrm{BC}_{1}$ & SER-16 $\times($ Roba-1 $\times$ SER-16) & SAB-623 $\times($ Melka-Dima $\times$ SAB-623) \\
$\mathrm{BC}_{2}$ & Roba-1 $\times($ Roba-1 $\times$ SER-16) & Melka-Dima $\times($ Melka-Dima $\times$ SAB-623) \\
\hline
\end{tabular}

mark (IRROMETER CAMPANY, INC). The water marks were installed at six levels of depth ( 0 to 5,5 to 10,10 to 20, 20 to 40,40 to 60 , and 60 to $80 \mathrm{~cm}$ ) at randomly selected sites in each block/replication. Reading was taken twice between each irrigation with water mark readings 0 to 10 centibars (soil moisture is at field capacity), 10 to 30 centibars (soil is adequately wet), 30 to 60 centibars (soil usually range for irrigation), above 100 centibars (soil is becoming dangerously dry for maximum production). Using this information on soil moisture status, the irrigation frequency was adjusted accordingly. For control (non-stressed) treatments, the 
Table 2. Scaling test for morpho-physiological characteristics in Roba-1 $\times$ SER-16 (C1) and Melka-Dima $\times$ SAB-623 (C2) crosses grown under drought stress (DS) and non- stress (NS) conditions at Melkassa, Central Rift Valley of Ethiopia.

\begin{tabular}{|c|c|c|c|c|c|c|c|}
\hline \multirow{2}{*}{\multicolumn{2}{|c|}{$\begin{array}{l}\text { Scaling test } \\
\text { Cross }\end{array}$}} & \multicolumn{3}{|c|}{ Roba-1 $\times$ SER-16 } & \multicolumn{3}{|c|}{ Melka-Dima $\times$ SAB-623 } \\
\hline & & A & B & C & A & B & C \\
\hline \multirow{2}{*}{$\mathrm{PH}$} & NS & $4.00 \pm 3.71$ & $-7.47 \pm 4.39$ & $-12.33 \pm 6.05^{\star}$ & $-1.00 \pm 2.25$ & $-8.40 \pm 2.39^{\star \star}$ & $-13.40 \pm 3.86^{\star \star}$ \\
\hline & DS & $1.40 \pm 2.75$ & $-1.87 \pm 2.75$ & $-16.87 \pm 4.22^{\star *}$ & $-4.10 \pm 9.63$ & $-0.70 \pm 9.25$ & $-11.33 \pm 20.04$ \\
\hline \multirow{2}{*}{ PL } & NS & $-0.71 \pm 0.28^{*}$ & $-1.14 \pm 0.34^{\star \star}$ & $-4.19 \pm 6.49$ & $-1.02 \pm 3.73$ & $-1.14 \pm 3.67$ & $-2.98 \pm 7.50$ \\
\hline & DS & $-1.07 \pm 2.65$ & $-1.48 \pm 0.37^{* *}$ & $-3.80 \pm 6.69$ & $-1.18 \pm 3.96$ & $-1.52 \pm 4.15$ & $-3.82 \pm 8.10$ \\
\hline \multirow{2}{*}{ gs } & NS & $-64.59 \pm 41.18$ & $-69.03 \pm 45.03$ & $-166.45 \pm 97.61$ & $-42.74 \pm 9.60^{\star \star}$ & $-14.52 \pm 10.78$ & $-225.5 \pm 18.34^{\star \star}$ \\
\hline & DS & $-47.45 \pm 35.79$ & $-89.00 \pm 40.82^{*}$ & $-236.65 \pm 85.63^{* *}$ & $-28.29 \pm 10.08^{* *}$ & $-16.86 \pm 9.67$ & $-91.01 \pm 87.70$ \\
\hline \multirow{2}{*}{ CT } & NS & $-1.35 \pm 0.47^{\star}$ & $-1.38 \pm 0.834$ & $-0.06 \pm 1.282$ & $-2.49 \pm 0.78^{\star *}$ & $1.07 \pm 0.86$ & $1.69 \pm 1.34$ \\
\hline & DS & $-2.87 \pm 0.88^{\star}$ & $1.19 \pm 0.94$ & $6.86 \pm 1.41^{* *}$ & $2.49 \pm 0.97^{\star}$ & $0.91 \pm 0.96$ & $6.97 \pm 7.64$ \\
\hline \multirow{2}{*}{ QY } & NS & $-0.051 \pm 0.079$ & $-0.035 \pm 0.081$ & $-0.074 \pm 0.172$ & $-0.06 \pm 0.07$ & $-0.05 \pm 0.02^{*}$ & $-0.26 \pm 0.18$ \\
\hline & DS & $-0.04 \pm 0.02^{\star}$ & $-0.028 \pm 0.02$ & $-0.19 \pm 0.03^{*}$ & $-0.05 \pm 0.02^{*}$ & $-0.03 \pm 0.02$ & $-0.22 \pm 0.17$ \\
\hline \multirow{2}{*}{ LA } & NS & $-13.88 \pm 14.18$ & $-10.83 \pm 3.47^{* *}$ & $-58.30 \pm 30.27$ & $-16.94 \pm 13.81$ & $-15.83 \pm 3.46^{* *}$ & $-52.78 \pm 33.35$ \\
\hline & DS & $-6.522 \pm 13.91$ & $-8.878 \pm 3.60^{*}$ & $-48.289 \pm 28.92$ & $-13.06 \pm 14.07$ & $-16.6 \pm 4.07^{\star *}$ & $-50.8 \pm 33.05$ \\
\hline
\end{tabular}

$\mathrm{PH}$, Plant height $(\mathrm{cm})$; PL, pod length $(\mathrm{cm})$; gs, stomatal conductance (mmol m$\left.{ }^{-2} \mathrm{~s}^{-1}\right)$; CT, canopy temperature $\left({ }^{\circ} \mathrm{C}\right)$; Qy, quantum yield; LA, leaf area $\left(\mathrm{cm}^{2}\right)$; NS, non- stress; DS, drought stress; ${ }^{*}$ and ${ }^{* *}$ significant at 5 and $1 \%$ level of probability, respectively.

plots were irrigated to restore the soil moisture status to field capacity until physiological maturity. Since the non-segregating generation represents the homozygous population while segregating generation represents heterozygous population, the number of plants used for the different generations was varied. Accordingly, there were two rows per plot for $P_{1}, P_{2}, F_{1}, B C_{1}$ and $\mathrm{BC}_{2}$ generations and four rows per plot for $\mathrm{F}_{2}$ generation. The row length was $2 \mathrm{~m}$ and the rows were kept at $0.6 \mathrm{~m}$ apart. Within row spacing (distance between plants) was $0.1 \mathrm{~m}$. Fertilizers were applied at planting using the rate of $46 \mathrm{P}_{2} \mathrm{O}_{5} \mathrm{~kg} \mathrm{ha}^{-1}$ in the form of DAP and other crop management was carried out as recommended for the area.

\section{Data collection}

Pod length, plant height, number of pods per plant, seeds per pod and seed yield per plant were determined on ten and five randomly selected plants for $F_{2}$ and the other five generations, respectively. Leaf area $\left(\mathrm{LA}, \mathrm{cm}^{2}\right.$ ) was measured using a non-destructive method developed as standard system for the evaluation of bean leaf area (Habtu, 1994). Seed yield per hectare was obtained by converting plot yield and adjusting seed moisture content at $10 \%$. Above ground biomass (AGB, gm plant ${ }^{-1}$ ) was considered as weight of above ground parts (stem + leaves +pod wall + seed) at harvest after drying for $48 \mathrm{~h}$ at $85^{\circ} \mathrm{C}$ randomly selected plants. Harvest index $(\mathrm{HI})$ was determined as proportion of seed weight to the AGB at harvesting dry weight (stem + leaves +pod wall + seed) at harvest $\times 100$.

Leaf chlorophyll content (SPAD value) was measured by using a non-destructive, hand-held chlorophyll meter (SPAD-502 chlorophyll meter, Minolta Camera Co., Ltd., Japan). Canopy temperature $\left(\mathrm{CT} ;{ }^{\circ} \mathrm{C}\right)$ was considered as the difference in temperature between the leaf canopy and the surrounding air temperature measured using an infrared thermometer (Telatemp model AG-42D, Telatemp CA, USA). Stomatal conductance (mmol $\mathrm{m}^{-2} \mathrm{~s}^{-1}$ ) for water vapor was measured using a portable leaf porometer (leaf porometer, Decagon Devices INC). The photo system II quantum yield (quantum yield, QY) was measured by using a non-destructive, hand-held Qy meter (Fluorpen, FP100, Photo systems Instruments).

\section{Data analysis}

Data were subjected to the generation mean analysis to determine the type of genetic variation associated with each trait under the two watering regimes. Mather (1949) scaling tests were employed to detect the presence of epistasis. To obtain information on the nature of gene action governing the traits under study, all the six components of generation means were computed. In the presence of epistasis, generation mean analyses were carried out according to Hayman (1958). The significance of the different parameters was tested with the help of ' $t$ ' values, which were calculated for each component by dividing the gene effect of respective components by their standard errors (SE). Data were subjected to the estimation of various components (environmental, genotypic, additive and dominance) variances as per Mather and Jinks (1971). Broad and narrow sense heritabilities were calculated following the method used by Mather (1949).

\section{RESULTS}

\section{Estimates of gene action}

Scaling test for Roba-1 $\times$ SER-16 cross has demonstrated that all morpho-physiological characters (except stomatal conductance and quantum yield under non-stress) were significant under both watering regimes (Table 2). In Melka-Dima $\times$ SAB-623 cross, all 


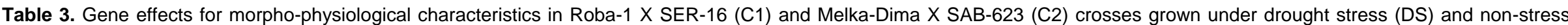
(NS) conditions at Melkassa, Central Rift Valley of Ethiopia.

\begin{tabular}{|c|c|c|c|c|c|c|c|c|c|c|c|c|c|}
\hline \multirow{2}{*}{ Cross } & \multirow{2}{*}{$\begin{array}{l}\text { Gene } \\
\text { effect }\end{array}$} & \multicolumn{2}{|c|}{$\mathrm{PH}$} & \multicolumn{2}{|c|}{$\mathrm{PL}$} & \multicolumn{2}{|c|}{ gs } & \multicolumn{2}{|c|}{$\mathrm{CT}$} & \multicolumn{2}{|c|}{ Qy } & \multicolumn{2}{|c|}{ LA } \\
\hline & & NS & DS & NS & DS & NS & DS & NS & DS & NS & DS & NS & DS \\
\hline \multirow{7}{*}{$\mathrm{C} 1$} & $\mathrm{~m}$ & $43.3 \pm 1.12^{* *}$ & $38.3 \pm 0.77^{* *}$ & $8.2 \pm 0.09^{* *}$ & $7.3 \pm 0.10^{\star *}$ & $233.6 \pm 3.25^{* *}$ & $176.2 \pm 2.9^{* *}$ & $15.6 \pm 0.23^{* *}$ & $19.5 \pm 0.25^{* *}$ & $0.45 \pm 0.005^{* *}$ & $0.387 \pm 0.005^{* *}$ & $68.9 \pm 1.04^{* *}$ & $61.4 \pm 1.02^{* *}$ \\
\hline & $d$ & $-1.1 \pm 2.24$ & $-1.8 \pm 1.55$ & $-0.2 \pm 0.19$ & $0.4 \pm 0.20$ & $-3.9 \pm 6.51$ & $30.1 \pm 5.9^{\star *}$ & $-0.8 \pm 0.46$ & $-4.0 \pm 0.51^{* *}$ & $-0.042 \pm 0.011^{*}$ & $0.008 \pm 0.011$ & $-3.6 \pm 2.09$ & $6.2 \pm 2.05^{\star *}$ \\
\hline & $\mathrm{h}$ & $12.0 \pm 6.64$ & $20.6 \pm 4.58^{\star *}$ & $2.5 \pm 0.57^{* *}$ & $2.2 \pm 0.61^{* *}$ & $72.4 \pm 19.27^{* *}$ & $143.1 \pm 17.4^{* \star}$ & $-3.5 \pm 1.36^{*}$ & $-9.8 \pm 1.53^{* *}$ & $0.042 \pm 0.035$ & $0.155 \pm 0.033^{* *}$ & $38.2 \pm 6.19^{* \star}$ & $38.2 \pm 6.09^{* *}$ \\
\hline & $\mathrm{i}$ & $8.9 \pm 6.34$ & $16.4 \pm 4.38^{* *}$ & $2.3 \pm 0.54^{* *}$ & $1.3 \pm 0.58^{\star}$ & $32.8 \pm 18.42$ & $100.2 \pm 16.7^{* *}$ & $-2.7 \pm 1.30^{*}$ & $-8.5 .46^{* *}$ & $-.011 \pm 0.033$ & $0.122 \pm 0.031^{* *}$ & $33.6 \pm 5.92^{* *}$ & $32.9 \pm 5.82^{* *}$ \\
\hline & j & $11.5 \pm 5.01^{*}$ & $3.3 \pm 3.46$ & $0.4 \pm 0.43$ & $0.4 \pm 0.46$ & $4.4 \pm 14.56$ & $41.5 \pm 13.2^{* \star}$ & $0.03 \pm 1.03$ & $-4.1 \pm 1.16^{\star \star}$ & $-0.015 \pm 0.026$ & $-0.009 \pm 0.025^{\star *}$ & $-3.1 \pm 4.68$ & $2.4 \pm 4.60$ \\
\hline & i & $-5.4 \pm 10.76$ & $-15.9 \pm 7.43^{*}$ & $-0.5 \pm 0.92$ & $1.3 \pm 0.99$ & $100.8 \pm 31.24$ & $36.3 \pm 28.3$ & $5.4 \pm 2.21^{*}$ & $10.2 \pm 2.49^{* *}$ & $0.096 \pm 0.057$ & $-0.056 \pm 0.053$ & $-8.9 \pm 10.03$ & $-17.5 \pm 9.87$ \\
\hline & $\mathrm{m}$ & $37.6 \pm 0.69^{\star *}$ & $34.5 \pm 0.68^{\star *}$ & $10.0 \pm 0.12^{\star *}$ & $9.4 \pm 0.13^{* *}$ & $230.0 \pm 3.15^{* *}$ & $211.3 \pm 2.9^{* *}$ & $16.6 \pm 0.24^{\star *}$ & $20.7 \pm 0.26^{\star *}$ & $0.389 \pm 0.005^{\star *}$ & $0.379 \pm 0.005^{\star *}$ & $77.2 \pm 1.08^{* *}$ & $74.4 \pm 1.16$ \\
\hline \multirow{5}{*}{$\mathrm{C} 2$} & $d$ & $-0.7 \pm 1.39$ & $-2.6 \pm 1.34^{*}$ & $-0.04 \pm 0.24$ & $0.3 \pm 0.26$ & $-21.9 \pm 6.31^{\text {**}}$ & $5.4 \pm 5.8$ & $-1.9 \pm 0.48^{* *}$ & $-0.13 \pm 0.53$ & $-0.008 \pm 0.011$ & $0.009 \pm 0.011$ & $-7.8 \pm 2.17^{\star *}$ & $9.4 \pm 2.32$ \\
\hline & $\mathrm{h}$ & $5.9 \pm 4.12$ & $8.9 \pm 4.04^{*}$ & $1.5 \pm 0.72^{*}$ & $1.5 \pm 0.78^{\star}$ & $188.5 \pm 18.68^{* \star}$ & $66 . \pm 17.2^{* *}$ & $-4.3 \pm 1.42^{\star \star}$ & $-3.8 \pm 1.57^{*}$ & $0.190 \pm 0.033^{* *}$ & $0.191 \pm 0.034^{* *}$ & $24.2 \pm 6.44^{* *}$ & $35.1 \pm 6.89$ \\
\hline & $\mathrm{i}$ & $4.0 \pm 3.94$ & $6.5 \pm 3.85$ & $0.8 \pm 0.69$ & $1.12 \pm 0.75$ & $168.2 \pm 17.86^{* *}$ & $45.84 \pm 16.5^{* *}$ & $-3.1 \pm 1.36^{*}$ & $-3.6 \pm 1.50^{*}$ & $0.148 \pm 0.032^{* *}$ & $0.137 \pm 0.032^{* *}$ & $20.0 \pm 6.16^{* *}$ & $21.1 \pm 6.58$ \\
\hline & j & $7.4 \pm 3.11^{*}$ & $-3.4 \pm 3.05$ & $0.12 \pm 0.54$ & $0.34 \pm 0.59$ & $-28.2 \pm 14.11^{*}$ & $-8.57 \pm 13.0$ & $-3.6 \pm 1.07^{* *}$ & $1.6 \pm 1.19$ & $-0.008 \pm 0.025$ & $-0.021 \pm 0.025$ & $-1.1 \pm 4.87$ & $3.6 \pm 5.20$ \\
\hline & I & $5.4 \pm 6.69$ & $-1.7 \pm 6.54$ & $1.35 \pm 1.17$ & $1.58 \pm 1.27$ & $-110.9 \pm 30.28^{*}$ & $-0.68 \pm 27.9$ & $4.5 \pm 2.31^{*}$ & $0.17 \pm 2.55$ & $-0.036 \pm 0.054$ & $-0.054 \pm 0.055$ & $12.8 \pm 10.45$ & $8.6 \pm 11.17$ \\
\hline
\end{tabular}

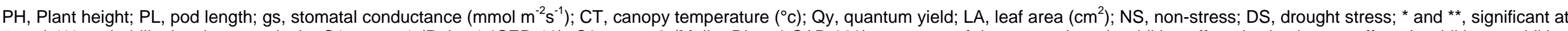

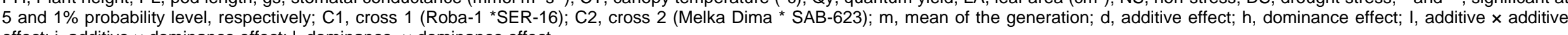
effect; j, additive $\times$ dominance effect; I, dominance $\times$ dominance effect.

morpho-physiological characters (except pod length) were significant for at least one of the scale tests under both watering regimes. Estimates of genetic effects for the six parameter model indicated that mean effect $(\mathrm{m})$ of each cross under the two watering regimes was significant (Table 3). Additive $x$ dominance (j) was significant under non-stress in both crosses for plant height. Under drought stress dominance, additive $\mathrm{x}$ additive and dominance $\mathrm{x}$ dominance for Roba- $1 \times$ SER-16 cross with duplicate types of epistasis and additive and dominance for MelkaDima $\times$ SAB-623 cross were significant (Table 3).

Dominance and additive $x$ additive were significant for pod length in Roba-1 $\times$ SER-16 cross under both watering regimes. In the MelkaDima $\times$ SAB-623 cross, only dominance was significant under both watering regimes. In the Roba-1 $\times$ SER-16 cross, dominance (h) under non-stress and additive, dominance, additive $\times$ additive and additive $\times$ dominance under drought stress were significant for stomatal conductance. Additive, dominance, additive $\times$ additive, additive $x$ dominance and dominance $x$ dominance with duplicate type of epistasis under non-stress and dominance, additive $\times$ additive under drought stress were significant in Melka-Dima $\times$ SAB-623 cross. For canopy temperature dominance, additive $\times$ additive and dominance $\times$ dominance with duplicate types of epistasis under non-stress and significant additive, additive, dominance, additive $\times$ additive, additive $\times$ dominance and dominance $x$ dominance with duplicate types of epistasis under drought stress were observed in Roba-1 $\times$ SER-16 cross. In Melka-Dima $\times$ SAB 623 cross, additive, dominance, additive $\times$ additive, additive $\times$ dominance and dominance with duplicate types of epistasis under non-stress and dominance and additive $\times$ additive under drought stress were significant.

Scaling test for A, B, and C was done for yield and yield components in the two crosses for each watering regime (Table 4). At least one of the scales was significant in Roba- $1 \times$ SER-16 cross for seed per plant, seed yield, above ground biomass and harvest index under both growth conditions whereas pod per plant was nonsignificant under both watering regimes. In MelkaDima $\times$ SAB-623 cross, all yield and yield components except above ground biomass were significant under the two watering regimes. Results of types of gene action estimated by generation mean analysis as genetic effects in six model parameter for yield and yield components are presented in Table 5. Results indicated that mean effect $(m)$ of each cross under the two watering regimes was significant. Additive gene 
Table 4. Scaling test for yield and yield components in two common bean crosses grown under drought stress (DS) and nonstress (NS) conditions at Melkassa, Central Rift Valley of Ethiopia.

\begin{tabular}{|c|c|c|c|c|c|c|c|}
\hline \multirow{2}{*}{ Cross } & \multirow{2}{*}{ WR } & \multicolumn{3}{|c|}{ Roba-1 $\times$ SER-16 } & \multicolumn{3}{|c|}{ Melka-Dima $\times$ SAB-623 } \\
\hline & & A & B & C & A & B & C \\
\hline \multirow{2}{*}{ NPPP } & NS & $-9.2 \pm 10.4$ & $-4.6 \pm 11.7$ & $-10.6 \pm 34.7$ & $4.3 \pm 1.8^{*}$ & $0.2 \pm 2.1$ & $-16.4 \pm 3.4^{\star \star}$ \\
\hline & DS & $-7.3 \pm 9.4$ & $-7.7 \pm 10.8$ & $-14.8 \pm 23.6$ & $4.5 \pm 2.0$ & $-5.5 \pm 1.9$ & $-14.9 \pm 5.5^{\star \star}$ \\
\hline \multirow{2}{*}{ NSPPI } & NS & $-2.0 \pm 24.1$ & $-16.4 \pm 6.7^{*}$ & $-58.1 \pm 75.7$ & $13.7 \pm 5.9^{*}$ & $2.9 \pm 6.3$ & $-53.9 \pm 9.2^{* *}$ \\
\hline & DS & $-1.1 \pm 8.8$ & $7.3 \pm 9.1$ & $-70.4 \pm 14.1^{\star \star}$ & $3.9 \pm 7.2$ & $-6.6 \pm 5.6$ & $-31.6 \pm 8.1^{* *}$ \\
\hline \multirow{2}{*}{ SYPP } & NS & $-11.2 \pm 2.7^{* *}$ & $-7.4 \pm 2.9^{\star *}$ & $-31.7 \pm 93.6$ & $7.9 \pm 2.7^{\star *}$ & $-16.2 \pm 2.3^{\star \star}$ & $-32.2 \pm 51.2$ \\
\hline & DS & $-6.3 \pm 3.0^{*}$ & $-1.6 \pm 2.2$ & $-17.4 \pm 42.0$ & $-6.4 \pm 2.9^{* *}$ & $-1.9 \pm 1.8$ & $-26.0 \pm 35.2$ \\
\hline \multirow{2}{*}{ AGB } & NS & $-103.3 \pm 15.5^{\star *}$ & $-67.5 \pm 22.8^{* *}$ & $-250.5 \pm 177.4$ & $10.3 \pm 78.9$ & $-184.4 \pm 65.7^{*}$ & $-281.1 \pm 187.1$ \\
\hline & DS & $-29.0 \pm 12.7^{\star}$ & $-29.2 \pm 17.3$ & $-225.6 \pm 25.2$ & $-7.2 \pm 17.4$ & $-10.2 \pm 13.1$ & $-6.9 \pm 27.9$ \\
\hline \multirow{2}{*}{$\mathrm{HI}$} & NS & $-6.2 \pm 3.8$ & $-6.4 \pm 3.2^{*}$ & $-24.9 \pm 32.3$ & $-4.1 \pm 3.6$ & $-6.4 \pm 3.4$ & $-24.3 \pm 5.8^{* *}$ \\
\hline & DS & $-5.2 \pm 3.5$ & $1.4 \pm 3.3$ & $-16.7 \pm 5.4^{\star *}$ & $-2.4 \pm 3.5$ & $-0.5 \pm 3.1$ & $-19.2 \pm 5.4^{* *}$ \\
\hline
\end{tabular}

NPPP, Number of pod per plant; NSPPI, number of seed per plant; SYPP, seed yield per plant; AGB, above ground biomass; HI, harvest index; WR, watering regime; NS, non-stress; DS, drought stress; * and ${ }^{* *}$, significant at 5 and $1 \%$ level of probability, respectively.

action was significant for pod per plant under non-stress and drought stress in the Roba-1 $\times$ SER-16 cross. On the other hand, dominance, additive $x$ additive and dominance $\times$ dominance with duplicate types of epistasis under non-stress and additive, dominance, additive $\times$ additive, additive $\times$ dominance and dominance $\times$ dominance with duplicate types of epistasis under drought stress were significant in Melka-Dima $\times$ SAB-623 cross. For seed per plant, additive $\times$ additive under nonstress and dominance and additive $\times$ additive under drought stress were significant in Roba-1 $\times$ SER-16 cross. In the Melka-Dima $\times$ SAB-623 cross, dominance, additive $\times$ additive and dominance $\times$ dominance with duplicate types of epistasis under non-stress and additive, dominance, additive $x$ additive and additive $\times$ dominance under drought stress were significant for seed per plant. The additive, dominance and additive $\times$ additive under non-stress and dominance, additive $x$ additive and dominance $\times$ dominance with duplicate types of epistasis under drought stress were significant for seed yield in Roba-1 x SER-16 cross. Similarly, additive, dominance, additive $\times$ additive, additive $x$ dominance and dominance $\times$ dominance with duplicate types of epistasis under non-stress and additive, dominance and additive $\times$ additive under drought stress were found in Melka-Dima $\times$ SAB-623 cross. Under nonstress condition additive, dominance and additive $x$ additive and under drought stress dominance and additive $\times$ additive were significant for above ground biomass in Roba- $1 \times$ SER-16 cross. Additive, dominance, additive $\times$ additive and additive $\times$ dominance were significant in Melka-Dima $\times$ SAB-623 cross under non-stress but only additive was significant under drought stress. Significant epistatic additive $\times$ additive type of gene effects was detected for harvest index in Roba- $1 \times$ SER-16 cross under both watering regimes. On the other hand, dominance and additive $\times$ additive were significant for the same parameter in Melka-Dima $\times$ SAB-623 cross under both watering regimes.

\section{Estimates of components of variance}

Estimates of variance components varied considerably between crosses and watering regimes (Table 6). Environmental component variance was less than the additive and dominance component of variance in both crosses under both growth conditions for all morphophysiological character considered. Additive variance was higher than dominance variance for stomatal conductance and quantum yield in both crosses under both watering regimes. The additive variance (VA) was larger than dominance variance (VD) for pod length under both watering regimes in Roba-1 $\times$ SER-16 cross. For leaf area, additive component of variance was higher than dominance component of variance in Melka-Dima $\times$ SAB-623 cross under both environmental condition and under non-stress condition in Roba- $1 \times$ SER-16 cross. Additive component of variance was less than dominance component of variance in Roba- $1 \times$ SER-16 cross for plant height and canopy temperature under the two watering regimes. Under drought stress, additive component of variance was less than dominance component of variance in Roba- 1 × SER-16 cross for leaf 
Table 5. Gene effects for yield and yield components in two common bean crosses grown under drought stress (DS) and non-stress (NS) conditions at Melkassa, Central Rift Valley of Ethiopia.

\begin{tabular}{|c|c|c|c|c|c|c|c|c|c|c|c|}
\hline \multirow{2}{*}{ Cross } & \multirow{2}{*}{$\begin{array}{l}\text { Gene } \\
\text { effect }\end{array}$} & \multicolumn{2}{|c|}{ NPPP } & \multicolumn{2}{|c|}{ NSPPI } & \multicolumn{2}{|c|}{ SYPP } & \multicolumn{2}{|c|}{ AGB } & \multicolumn{2}{|c|}{$\mathrm{HI}$} \\
\hline & & NS & DS & NS & DS & NS & DS & NS & DS & NS & DS \\
\hline & $\mathrm{m}$ & $29.9 \pm 1.0^{* *}$ & $24.1 \pm 0.8^{* *}$ & $123.1 \pm 2.3^{* *}$ & $97.3 \pm 2.6^{* *}$ & $26.9 \pm 0.8^{* *}$ & $24.0 \pm 0.8^{* *}$ & $236.3 \pm 5.9^{* *}$ & $178.9 \pm 4.5^{* *}$ & $56.7 \pm 1.1^{* *}$ & $52.6 \pm 0.9^{* *}$ \\
\hline & $d$ & $-3.9 \pm 1.9^{*}$ & $3.9 \pm 1.5^{*}$ & $-3.2 \pm 4.6$ & $7.4 \pm 5.2$ & $-4.0 \pm 1.6^{*}$ & $0.5 \pm 1.6$ & $-43.8 \pm 11.9^{* *}$ & $11.2 \pm 9.0$ & $-1.7 \pm 2.2$ & $1.7 \pm 1.9$ \\
\hline Roba-1 & $\mathrm{h}$ & $-3.5 \pm 6.1$ & $4.6 \pm 4.5$ & $26.0 \pm 3.7$ & $81.9 \pm 15.3^{* *}$ & $12.6 \pm 4.7^{\star *}$ & $16.4 \pm 4.7^{\star \star}$ & $72.7 \pm 35.3^{*}$ & $11.2 \pm 9.0^{* *}$ & $10.7 \pm 6.4$ & $15.3 \pm 5.8$ \\
\hline \multirow[t]{5}{*}{ × SER-16 } & $\mathrm{i}$ & $-3.2 \pm 5.8$ & $-0.1 \pm 4.3$ & $39.6 \pm 13.1^{* *}$ & $76.7 \pm 14.6^{* *}$ & $13.2 \pm 4.5^{\star}$ & $9.5 \pm 4.5^{\star}$ & $79.7 \pm 33.7^{*}$ & $167.3 \pm 25.4^{* *}$ & $12.3 \pm 6.1^{*}$ & $12.9 \pm 5.6^{* *}$ \\
\hline & j & $-4.6 \pm 4.6$ & $0.4 \pm 3.4$ & $14.3 \pm 10.4$ & $-8.4 \pm 11.5$ & $-3.8 \pm 3.6$ & $-4.7 \pm 3.6$ & $-35.8 \pm 26.6$ & $0.2 \pm 20.1$ & $0.23 \pm 4.8$ & $-6.6 \pm 4.4$ \\
\hline & I & $17.1 \pm 9.8$ & $15.1 \pm 7.3$ & $-21.2 \pm 22.3$ & $-82.8 \pm 24.7$ & $5.3 \pm 7.7$ & $-1.5 \pm 7.6^{*}$ & $91.1 \pm 57.2$ & $-109.1 \pm 43.1^{*}$ & $0.3 \pm 10.3$ & $-9.3 \pm 9.4$ \\
\hline & $\mathrm{m}$ & $19.5 \pm 0.6^{* *}$ & $15.5 \pm 0.6^{* *}$ & $58.9 \pm 1.7^{\star *}$ & $45.0 \pm 1.9^{\star *}$ & $28.4 \pm 0.7^{\star *}$ & $17.5 \pm 0.7^{\star \star}$ & $251.3 \pm 5.9^{* *}$ & $198.1 \pm 4.8^{\star *}$ & $56.2 \pm 1.0^{* *}$ & $52.3 \pm 0.9^{* *}$ \\
\hline & $d$ & $0.9 \pm 1.2$ & $8.5 \pm 1.2^{\star *}$ & $3.5 \pm 3.4$ & $12.9 \pm 3.9^{* *}$ & $10.7 \pm 1.5^{* *}$ & $4.2 \pm 1.5^{\star *}$ & $80.4 \pm 11.8^{* *}$ & $56.7 \pm 9.7^{\star *}$ & $-0.8 \pm 2.1$ & $1.0 \pm 1.9$ \\
\hline Melka-Dima & $\mathrm{h}$ & $25.0 \pm 3.4^{* *}$ & $14.9 \pm 3.5^{\star *}$ & $82.1 \pm 10.1^{* *}$ & $36.5 \pm 11.6^{* *}$ & $22.7 \pm 4.5^{\star *}$ & $18.5 \pm 4.4^{* *}$ & $112.2 \pm 35.0^{* *}$ & $-5.0 \pm 28.7$ & $13.7 \pm 6.1^{*}$ & $17.2 \pm 5.7^{\star \star}$ \\
\hline \multirow[t]{3}{*}{$\times$ SAB-623 } & $\mathrm{i}$ & $20.9 \pm 3.3^{* *}$ & $14.0 \pm 3.3^{* *}$ & $70.5 \pm 9.7^{\star *}$ & $28.9 \pm 11.1^{\star *}$ & $23.9 \pm 4.3^{\star *}$ & $17.7 \pm 4.3^{\star *}$ & $106.9 \pm 33.5^{\star *}$ & $-10.5 \pm 27.4$ & $13.8 \pm 5.8^{*}$ & $16.3 \pm 5.5^{\star \star}$ \\
\hline & j & $4.2 \pm 2.6$ & $10.0 \pm 2.6^{* *}$ & $10.8 \pm 7.7$ & $10.6 \pm 8.8^{* *}$ & $24.2 \pm 3.4^{* *}$ & $-4.4 \pm 3.4$ & $194.8 \pm 26.4^{* *}$ & $2.9 \pm 21.7$ & $2.3 \pm 4.6$ & $-1.9 \pm 4.3$ \\
\hline & i & $-25.4 \pm 5.5^{\star *}$ & $-13.1 \pm 5.6^{*}$ & $-87.1 \pm 16.4^{* *}$ & $-26.2 \pm 18.8$ & $-15.7 \pm 7.4^{*}$ & $-9.4 \pm 7.3$ & $67.5 \pm 56.7$ & $27.9 \pm 46.6$ & $-3.4 \pm 9.9$ & $-13.4 \pm 9.3$ \\
\hline
\end{tabular}

NPPP, number of pod per plant; NSPPI, number of seed per plant); SYPP, (seed yield per plant); AGB, above ground biomass; HI, harvest index; NS, non-stress; DS, drought stress; * and ${ }^{* *}$, significant at 5 and $1 \%$ probability level, respectively; C1, cross 1 (Roba-1 $\times$ SER-16); C2, cross 2 (Melka-Dima $\times$ SAB-623); m, mean of the generation, d, additive effect; h, dominance effect; I, additive $\times$ additive effect; j, additive $x$ dominance effect; I, dominance $\times$ dominance effect.

area. In Melka-Dima $\times$ SAB-623 cross, dominance component of variance was higher than additive component of variance for canopy temperature under drought stress. The VA was larger than VD for pod per plant, seed per plant, seed yield per plant, seed yield $(\mathrm{kg} / \mathrm{ha}), A G B$ and harvest index in both crosses under the two watering regimes. Environmental component of variance was less than the VA and VD for pod per plant, seed per plant, seed yield per plant, seed yield $(\mathrm{kg} / \mathrm{ha})$, AGB and harvest index for both crosses under the contrasting soil moisture regimes.

\section{Heritability}

Considerable differences were also found between the two crosses and the two soil moisture regimes for broad and narrow sense heritability of the growth and yield related traits (Table 7). Broad sense heritability ranged from $75.6 \%$ (leaf area) to $95.4 \%$ (for plant height) under non-stress and from $68.6 \%$ (leaf area) to $90.1 \%$ (for plant height) under drought stress in Roba-1 $\times$ SER-16 cross. In Melka-Dima $\times$ SAB-623 cross, it ranged from $83.6 \%$ (quantum yield) to $89.6 \%$ (canopy temperature) under non-stress and from $71.3 \%$ (leaf area) to $93.5 \%$ (plant height) under drought stress condition (Table 7). Narrow-sense heritabilities ranged from $36.1 \%$ (quantum yield) to $49.9 \%$ (stomatal conductance) under nonstress, and from $24.6 \%$ (leaf area) to $49.6 \%$ (stomatal conductance) under drought stress in the Roba-1 $\times$ SER-16 cross. In Melka-Dima $\times$ SAB-623 cross, narrow sense heritability was low to moderate under both moisture regimes, ranging from $18.5 \%$ (pod length) to $78.9 \%$ (quantum yield) under non-stress and from $8.7 \%$ (canopy temperature) to $58.2 \%$ (quantum yield) under drought stress. Broad sense heritabilities were high in Roba-1 $\times$ SER-16 under both growth conditions for all yield and yield components, ranging from $62.7 \%$ (above ground biomass) to $88.6 \%$ (pod per plant) under non-stress and from $72.02 \%$ (pod per plant) to $92.4 \%$ (AGB) under drought stress condition. In contrast, broad sense heritabilities in Melka-Dima $\times$ SAB-623 cross were moderate to high under non-stress $(36.1$ to $93.04 \%)$ and low to high under drought stress (15.24 to 93.2\%). In Roba-1 x SER-16 cross, narrow sense heritabilities ranged between $37.1 \%$ 
Table 6. Components of variance for morpho-physiological, yield and yield related traits in two crosses of common bean grown under drought stress (DS) and non-stress (NS) conditions at Melkassa, Central Rift Valley of Ethiopia.

\begin{tabular}{|c|c|c|c|c|c|c|c|c|c|}
\hline \multirow{2}{*}{ Cross } & \multirow{2}{*}{ Traits } & \multicolumn{2}{|c|}{ VE } & \multicolumn{2}{|c|}{ VG } & \multicolumn{2}{|c|}{ VA } & \multicolumn{2}{|c|}{ VD } \\
\hline & & NS & DS & NS & DS & NS & DS & NS & DS \\
\hline \multirow{11}{*}{$\begin{array}{l}\text { Roba-1 } \\
\times \text { SER-16 }\end{array}$} & $\mathrm{PH}$ & 3.1 & 3.0 & 63.2 & 27.6 & 11.3 & 7.9 & 51.9 & 19.6 \\
\hline & $\mathrm{PL}$ & 0.5 & 0.9 & 1.4 & 0.9 & 1.6 & 0.9 & 0.3 & 0.1 \\
\hline & gs & 95.6 & 93.7 & 460.9 & 334.1 & 277.7 & 212.5 & 183.2 & 121.6 \\
\hline & CT & 0.3 & 0.4 & 2.6 & 3.1 & 1.1 & 1.1 & 1.4 & 1.9 \\
\hline & QY & 0.0 & 0.0 & 0.001 & 0.001 & 0.001 & 0.003 & 0.001 & 0.003 \\
\hline & LA & 12.8 & 14.7 & 39.9 & 32.2 & 22.8 & 11.5 & 17.1 & 20.6 \\
\hline & NPPP & 8.1 & 7.7 & 62.6 & 19.9 & 41.6 & 12.7 & 12.7 & 21.0 \\
\hline & NSPPI & 67.3 & 64.8 & 270.3 & 263.7 & 265.4 & 118.3 & 118.3 & 4.9 \\
\hline & SYPP & 7.2 & 8.6 & 23.3 & 22.9 & 11.3 & 18.3 & 18.3 & 12.0 \\
\hline & AGB & 639.7 & 87.3 & 1073.6 & 1060.3 & 1031.2 & 670.1 & 670.1 & 42.4 \\
\hline & $\mathrm{HI}$ & 11.0 & 4.9 & 49.8 & 47.4 & 29.7 & 25.0 & 25.0 & 20.1 \\
\hline \multirow{11}{*}{$\begin{array}{l}\text { Melka-Dima } \\
\times \text { SAB-623 }\end{array}$} & $\mathrm{PH}$ & 3.6 & 1.6 & 22.3 & 22.9 & 14.7 & 6.1 & 7.6 & 16.9 \\
\hline & PL & 1.3 & 1.8 & 1.7 & 1.6 & 0.6 & 0.4 & 1.2 & 1.3 \\
\hline & gs & 78.7 & 60.3 & 491.5 & 397.5 & 437.1 & 243.9 & 54.4 & 153.6 \\
\hline & CT & 0.3 & 0.4 & 2.8 & 3.1 & 1.5 & 0.3 & 1.3 & 2.8 \\
\hline & QY & 0.0 & 0.0 & 0.002 & 0.001 & 0.001 & 0.001 & 0.0 & 0.0 \\
\hline & LA & 10.1 & 18.0 & 55.9 & 44.7 & 49.5 & 31.8 & 6.4 & 12.9 \\
\hline & NPPP & 8.2 & 8.7 & 4.6 & 2.7 & 2.8 & 1.7 & 1.8 & 1.1 \\
\hline & NSPPI & 18.2 & 94.9 & 129.3 & 17.1 & 37.2 & 3.9 & 92.2 & 13.2 \\
\hline & SYPP & 9.8 & 6.4 & 19.4 & 24.9 & 18.6 & 23.13 & 0.8 & 1.8 \\
\hline & AGB & 149.8 & 185.4 & 2002.6 & 1174.9 & 1848.1 & 1120.3 & 154.6 & 54.7 \\
\hline & $\mathrm{HI}$ & 5.1 & 3.6 & 55.2 & 49.3 & 34.3 & 27.6 & 20.9 & 21.7 \\
\hline
\end{tabular}

PH, Plant height; PL, pod length; gs, stomatal conductance; CT, canopy temperature; Qy, quantum yield; LA, leaf area; NPPP, number of pod per plant; NSPPI, number of seed per plant; SYPP, seed yield per plant; AGB, above ground biomass; HI, harvest index; VE, environmental variance; VG, genotypic variance; VA, additive variance; VD, dominance variance.

(for seed yield per plant) to $78.6 \%$ (for seed per plant) under non-stress and between $36.01 \%$ (seed yield per plant) and $58.39 \%$ (AGB) under drought stress condition. In MelkaDima $\times$ SAB623 cross, it was moderate to high under non-stress $(22.05 \%$ for pod per plant to $85.8 \%$ for AGB) and low to high under drought stress $3.5 \%$ (for seed per plant) to $82.4 \%$ (for AGB).

\section{DISCUSSION}

Analysis of variance depicted significant variation among generations and generation $\times$ watering regimes for most of the characters considered indicating the presence of genetic variability and possibility of selection for drought resistance. Information about the genetic components of variation helps the breeder in the selection of desirable parents for crossing programs and also in deciding a suitable breeding procedure for the genetic improvement of various quantitative traits (Singh and Narayanan, 1993). In both crosses, all morpho-physiological characters (except stomatal conductance and quantum yield under non-stress in Roba- $1 \times$ SER-16 cross and pod length in Melka-Dima $\times$ SAB-623 cross) were significant for at least one of the scaling tests under both watering regimes. The significance of any one of the scale reveals the presence of non-allelic interaction, revealing that the estimate of genetic parameters of the trait does not fit to the additive-dominance model. In both crosses, most of the yield related traits were significant under both watering regimes indicating absence of epistatic interaction effect. For plant height, pod length, stomatal conductance, canopy temperature, leaf area, pods per plant, seed per plant, seed yield (gm/plant), above ground biomass and harvest index, epistatic gene effect was present in one of the two crosses. Hence, additive genetic model was not sufficient to explain most of the genetic variation for the expression of these traits concurring the findings of Asrat and Kimani (2005). Under such conditions, epistatic effects have contributed to the inheritance of these traits in both crosses.

Because of the presence of epistasis, generation mean analyses were carried out according to Hayman (1958). The additive, dominance and epistatic types of gene interaction in each cross for different trait were found to be different from each other under different watering regimes. The generation mean analysis has brought out that individual crosses greatly differed for the gene action and on an overall basis all types of gene action, additive, dominance and epistasis were important. The results 
Table 7. Broad and narrow sense heritabilities of morpho-physiological, yield and yield related traits in two crosses of common bean grown under drought stress (DS) and non-stress (NS) conditions at Melkassa, Central Rift Valley of Ethiopia.

\begin{tabular}{|c|c|c|c|c|c|}
\hline \multirow{2}{*}{ Cross } & \multirow{2}{*}{ Traits } & \multicolumn{2}{|c|}{$h^{2} b$} & \multicolumn{2}{|c|}{$h^{2} n$} \\
\hline & & NS & DS & NS & DS \\
\hline \multirow{11}{*}{ Roba-1 × SER-16 } & $\mathrm{PH}$ & 95.4 & 90.1 & 17.1 & 25.9 \\
\hline & PL & 72.1 & 50.8 & 58.4 & 45.2 \\
\hline & gs & 82.8 & 78.1 & 49.9 & 49.7 \\
\hline & $\mathrm{CT}$ & 89.8 & 88.6 & 39.3 & 31.7 \\
\hline & QY & 80.1 & 84.2 & 36.1 & 29.7 \\
\hline & LA & 75.7 & 68.6 & 43.2 & 24.6 \\
\hline & NPPP & 88.6 & 72.0 & 58.9 & 46.0 \\
\hline & NSPPI & 80.1 & 80.3 & 78.6 & 36.0 \\
\hline & SYPP & 76.4 & 72.7 & 37.1 & 58.4 \\
\hline & AGB & 62.7 & 92.4 & 60.2 & 58.4 \\
\hline & $\mathrm{HI}$ & 81.9 & 90.6 & 48.8 & 47.8 \\
\hline \multirow{11}{*}{ Melka-Dima $\times$ SAB-623 } & $\mathrm{PH}$ & 86.2 & 93.5 & 56.9 & 24.7 \\
\hline & PL & 57.5 & 47.8 & 18.5 & 11.1 \\
\hline & gs & 86.2 & 86.8 & 76.7 & 53.3 \\
\hline & CT & 89.6 & 88.9 & 47.7 & 8.7 \\
\hline & QY & 83.6 & 76.3 & 78.9 & 58.0 \\
\hline & LA & 84.7 & 71.3 & 75.0 & 50.7 \\
\hline & NPPP & 36.1 & 23.8 & 22.1 & 14.6 \\
\hline & NSPPI & 87.6 & 15.2 & 25.2 & 3.5 \\
\hline & SYPP & 66.5 & 79.7 & 63.9 & 73.9 \\
\hline & AGB & 93.0 & 86.4 & 85.9 & 82.4 \\
\hline & $\mathrm{HI}$ & 91.5 & 93.2 & 56.9 & 52.3 \\
\hline
\end{tabular}

$\mathrm{PH}$, Plant height; PL, pod length; gs, stomatal conductance; CT, canopy temperature; Qy, quantum yield; LA, leaf area; NPPP, number of pod per plant; NSPPI, number of seed per plant; SYPP, seed yield per plant; AGB, above ground biomass; $\mathrm{HI}$, harvest index; $h^{2} b$, broad sense heritability; $h^{2} n$, narrow sense heritability.

indicated that mean effect $(m)$ of each cross under the two watering regimes was significant for all characters implying the difference in these characters among the parents. High significance for the estimated values of mean effects $(\mathrm{m})$ indicated that all the traits considered were quantitatively inherited under the contrasting soil moisture regimes. The significant additive $\times$ dominance (j) gene action found for plant height under non-stress condition in both crosses is in agreement with the reports of Vaid et al. (1985) and Melaku (1993) who found both additive and non-additive (dominance and epistasis) gene actions for the same trait. Dominance and additive $\times$ additive (in Roba-1 $\times$ SER-16 cross) and only dominance (in Melka-Dima $\times$ SAB-623 cross) gene actions for pod length under both watering regimes appear to slightly deviate from the results obtained by Arunga et al. (2010) and Carvalho et al. (1999) where epistatic effects were involved in addition to dominance in genetic control of pod length in snap bean.

The complex gene actions (involvement of both additive and non-additive) for stomatal conductance in both crosses and under the two soil moisture regimes are comparable with the expression of the trait in other crops such as wheat (Rebetzke et al., 2003). Similarly, the gene effects for the other physiological characteristics, canopy temperature, were complex in both crosses grown under drought stress and non-stress conditions conferring the results obtained for leaf temperature as drought resistance trait in cowpea (Chozin et al., 2006). The involvement of several gene actions for quantum yield and leaf area in both crosses imply that additive and dominance as well as epistasis gene action were important for inheritance of the physiological characters under different watering regimes.

The significant values of additive (d) and absence of digenic non allelic interaction in Roba-1 $\times$ SER-16 for pod per plant revealed that selection for this trait for drought resistance would be useful to start from the early segregating generation under drought stress condition. Similarly, significant values of additive, and the non-allelic gene interaction for pod per plant in Melka-Dima $\times$ SAB623 cross also showed less complexity in the inheritance of this trait for drought resistance. The dominance $(h)$ and dominance $x$ dominance $(I)$ effects were in the opposite direction, suggesting that duplicate-type epistasis occurred in most cases and indicating predominantly 
dispersed alleles at the interacting loci. Dominance gene effects were found to be relatively more important, as indicated by the fact that the dominance $(h)$ values were higher than the additive (d) values (Jinks and Jones, 1958). For seed per plant additive $\times$ additive under nonstress and dominance and additive $\mathrm{x}$ additive under drought stress were significant in. Presence of dominance $(h)$ gene effect and additive $\times$ additive (i) components under drought stress for Roba- $1 \times$ SER-16 cross suggests that the selection for seed per plant would be delayed till dominance and epistatic components are reduced selfing for drought resistance. According to Kunkaew et al. (2007), seed yield per plant is controlled by genes with significance in additive, dominance, and epistatic effects in adzuki bean suggesting that an effective selection to improve this trait should be mild in earlier generations and intense in later generations. The presence of additive $x$ additive effects for harvest index indicates the possibility of transgressive segregates in the later selfed generation besides being the only epistatic effect, at least theoretically, which could be effectively utilized in selection (Zimmerman et al., 1985). Similarly, Nigam et al. (2001) reported that in addition to additive and dominance effects, additive $\times$ additive types of epistasis which can be fixed in self pollinated crops was significant for harvest index.

Broad and narrow sense heritability estimates were found to be high in most of morpho-physiological characters for both crosses and under the two growth conditions. Similarly, Singh et al. (1994) reported the highest broad sense heritability for pod length and plant height. High heritability indicates that the environment least influenced these characters and selection based on mean would be successful in improving these traits. The low to high narrow sense heritability values under both watering regimes indicate medium chances of transmitting to the offspring the traits that determine bean productivity and improvement for these traits. Broad sense heritabilities were high in Roba- $1 \times$ SER-16 under both growth conditions and low to high under drought stress and moderate to high in Melka-Dima $\times$ SAB-623 cross for all yield and yield components. According to Escribano et al. (1994), heritabilities for seed yield and yield components varied from low to high in F2 and F3 generations of common bean. Farshadfar et al. (2008) also reported moderate narrow-sense heritability estimates for biological yield, harvest index, seed weight, and number of seed per plant in chick pea grown under drought stress. In both crosses, heritability in the broad sense as well as the narrow sense was slightly higher under non-stress compared with drought stress for all character (except seed yield), which is in agreement with the findings of Szilagyi (2003). According to Schneider et al. (1997), similar heritability in the broad and narrow sense found for yield and yield related traits between drought and non-stress conditions suggest that selection should be equally effective under different levels of stress.

\section{Conclusion}

The result of the present study generally showed that both additive and non-additive (dominance and epistatic) type of gene action were important in governing the inheritance of the characters studied. Since both additive and non-additive gene effects were of great importance in expression of the different traits, it is recommended that breeding methods, which make the best use of additive effects such as recurrent selection or diallel selection mating (DSM) and the pedigree method are applied to develop lines with resistance to drought in common bean. Presence of non-additive gene action for most of the yield related characters implies that conventional selection procedure may not be effective enough for improvement of yield for drought resistance. Therefore, postponement of selection in later generations or inter mating among the selected segregants followed by one or two generations of selfing could be suggested to break the undesirable linkage and allow the accumulation of favorable alleles for the improvement of desirable traits.

\section{ACKNOWLEDGEMENTS}

We thank the Ministry of Education of Ethiopia for the financial support. We are also grateful to Melkassa Agricultural Research Center for providing the germplasm and experimental facilities. The technical support of staff of the National Bean Research Program of Ethiopia is duly acknowledged.

\section{REFERENCES}

Abebe A, Brick MA, Kirkby R (1998). Comparison of selection induces to identify productive dry lines under diverse environmental conditions. Field Crops Res. 58:15-23.

Abreu de F, Ramalho MAP, Dos Santos J (2002). Prediction of seedyield potential of common bean populations. Gen. Mol. Biol. 25(3):323-327.

Arunga EE, Van Rheenen HA, Owuoche JO (2010). Diallel analysis of Snap bean (Phaseolus vulgaris L.) varieties for important traits. Afr. J. Agri. Res. 5(15):1951-1957.

Asrat A, Kimani PM (2005). Estimation of genetic parameters for some quantitative traits in large seeded bean (Phaseolus vulgaris L.) lines by factorial analysis of generation means. Afr. Crop Sci. Conf. Proc. 6:85-89.

Carvalho AC, Leal PP, Rodrigues NR, Costa FA (1999). Capacidade de combinação paraoito caracteres agronômicos em cultivares rasteiras de feijão-de-vagem. Hortic. Bras. 17:102-105.

Checa O, Ceballos HN, Blair MW (2006). Generation Means Analysis of Climbing Ability in Common Bean (Phaseolus vulgaris L.). J. Hered. $97(5): 456-465$.

Chozin M, Garner JO, Watson CE (2006). Inheritance of traits associated with drought resistance in cowpea. Jurnal IImu IImu Pertenian Indonesia. 8(1):1-5.

Chung WJ, Baggett, JR, Rowe KE (1991). Inheritance of pod crosssection in beans (Phaseolus vulgaris L.). Euphytica 53:159-164.

Cristina de FM, dos Santos JB, de Sousa Nunes GH, Ramalho MAP 
(2002). Choice of common bean parents based on combining ability estimates. Gen. Mol. Biol. 25(2):179-183.

Dabholkar AR (1999). Elements of Biometrical Genetics. Ashak Kumar Mitta, Concept Publishing Co. pp. 57-116.

Escribano MR, de AM, Amurrio JM (1994). Diversity in agronomical traits in common bean populations from Northwestern Spain. Euphytica 76:1-6.

Farshadfar E, Sabaghpour SH, Khaksar N (2008) Inheritance of drought tolerance in chickpea (Cicer arietinum L.) using joint scaling test. J. Appl. Sci. 8:3931-3937.

Ganesh SK, Sakila M (1999). Generation mean analysis in sesame (Sessamum indicum L.) crosses. Sesame and Safflower. News Lett. 14:8-14.

Hanson P, Pastor-Corrales M, Kornegay JL (1993). Heritability and sources of Ascochyta blight resistance in common bean. Plant Dis. 77:711-714.

Hayman BI (1958). The separation of epistatic from additive and dominance variation in generation mean. Heredity 12:371-390.

Jinks JL, Jones RM (1958). Estimation of the components of heterosis. Genetics 43:223-224.

Kornegay JL, Temple SR (1986). Inheritance and combining ability of leafhopper defense mechanisms in common bean. Crop Sci. 26:1153-1158.

Kunkaew W, Julsrigival S, Senthong CH, Karladee D (2007). Inheritance of seed yield in adzuki bean (Vigna angularis Willd). CMU. J. Nat. Sci. 6(2):341.

Laike S, Tilahun K, Hordofa T (2006). Crop coefficient of haricot bean at Melkassa, Central Rift Valley of Ethiopia. J. Agric. Rural Dev. Trop. Subtrop. 107(1):33-40.

Lamkey KR, Lee M (1993). Quantitative genetics, molecular markers, and plant improvement In: Imrie BC, Hacker, JB (ed.) Focused Plant Improvement. pp. 104-115.

Mather K (1949). Biometrical Genetics. In: The Study of Continuous Variation, Methun and Company Limited, London. P. 102.

Mather K, Jinks JL (1971). Biometrical Genetics: The Study of Continuous Variations. Chapman and Hall Ltd., London. P. 382.

Melaku A (1993). Heterosis and combining ability for yield and other quantitative characters in haricot bean (Phaseolus vulgaris L.). An MSc Thesis Presented to the School of Graduate Studies of Haramaya Univeristy. P. 103.

Nigam SN, Upadhyaya HD, Chandra S, Nageswarao RC, Wright GC (2001). Gene effect for specific leaf area and harvest index in three crosses of Groundnut. Ann. Appl. Bio. 139(30):1-306.
Park SJ, Timmins PR, Quiring DT, Jui PY (1994). Inheritance of leaf area and hooked trichome density of the first trifoliolate leaf in common bean (Phaseolus vulgaris L.). Can. J. Plant Sci. 74:235-240.

Rainey KM, Griffiths PD (2005). Inheritance of heat tolerance during reproductive development in snap bean (Phaseolus vulgaris L.). J. Am. Soc. Hortic. Sci. 30:700-706.

Rebetzke GJ, Condon AG, Richards RA, Farquhar GD (2003). Gene action for leaf conductance in three wheat crosses. Aust. J. Agri. Res. 54(4):381-387.

Sauter KJ, Davis DW, Li PH, Wallerstein IS (1990). Leaf ethylene evolution level following high-temperature stress in common bean. Hort. Sci. 25:1282-1284.

Schneider KA, Rosales-Serna R, Ibbara-Perez F, Cazares-Enriquez B, Acosta-Gallegos JA, Ramirez-Vallejo P, Wassimi N, Kelly JD (1997). Improving common bean performance under drought stress. Crop Sci. 37:43-50.

Sharmila V, Ganesh KS, Gunasekaran M (2007). Generation mean analysis for quantitative traits in sesame (Sesamum indicum L.) crosses. Gen. Mol. Biol. 30(1):80-84.

Singh DN, Nandi A, Tripathy P (1994). Genetic variability and character association in french bean ( $P$. vulgaris). Indian J. Agric. Sci. 64:114116.

Singh P, Narayanan SS (1993). Biometrical Techniques in Plant Breeding. 1st Edn. Kalayani Publishers NewDehli, India.

Szilagyi L (2003). Influence of drought on seed yield components in common bean. Bulg. J. Plant Physiol. pp. 320-330.

Thung M, Rao IM (1999). Integrated management of abiotic stresses. In S.P. Singh (ed.) Common bean improvement in the twenty-first century. Kluwer Academic Publishers, Dordrecht, the Netherlands. pp. 331-370

Vaid K, Singh RM, Gupta VP (1985). Combining ability in dry beans (Phaseolus vulgaris L.). J. Crop Improv. 12(2):255-258.

Zimmerman MJ, Rosielle ODA, Foster KW, Waines JG (1985). Gene action for grain yield and harvest index of common bean grown as sole crop and intercrop with maize. Field Crop Res. 12:319-329. 